\title{
SÍNDROME DE BURNOUT - LIMBO JURÍDICO PREVIDENCIÁRIO E TRABALHISTA
}

\section{BURNOUT SYNDROME - SOCIAL SECURITY AND LABOR LEGAL LIMBO}

\author{
Mara Vidigal Darcanhy ${ }^{1}$ \\ Maria Aparecida de Borba mendes ${ }^{3}$ \\ Eduardo Milléo Baracat ${ }^{3}$
}

\section{RESUMO}

Segundo o Anuário Estatístico de Acidentes de Trabalho, os transtornos mentais e comportamentais já ocupam o terceiro lugar em quantidade de concessões de auxílio doença acidentários, sendo estas as moléstias que mais afastaram os trabalhadores em 2011. Neste contexto, destaca-se maior relevância os segurados do INSS acometidos com alguma espécie de transtorno mental, como a "Síndrome do Esgotamento Profissional" - Síndrome de Burnout que, segundo pesquisadores, significa "queimar até a exaustão". Neste diapasão, sabe-se que o papel da prova pericial para a constatação desta doença e a consequente concessão do benefício previdenciário por incapacidade laborativa em juízo é de primordial importância, na medida em que é a partir deste laudo que o segurado será liberado, ou não, para retornar ao seu trabalho, independentemente da sua efetiva capacidade laboral, haja vista que nem sempre o médico da empresa o considera apto para exercer sua atividade, momento em que se depara com o limbo jurídico previdenciário trabalhista por estar sem benefício e sem salário, em vista da suspensão do pagamento devido à liberação do Expert, bem como, pela provável incapacidade configurada pelo empregador. Demonstrar-se-á, assim, o entendimento jurisprudencial e doutrinário em busca de uma resposta plausível para este problema que emerge de uma sociedade globalizada e assoberbada tecnologicamente, porém, sem uma

1 Doutora e Mestre em Direito das Relações Sociais pela Pontifícia Universidade Católica de São Paulo (PUC/SP). Realizou estágio Pós-Doutoral em Direito Internacional (UniPg/IT). Especialista em Didática do Ensino Superior; em Metodologia da Pesquisa e; em Direito do Trabalho (USP); Graduação em Direito e Licenciatura em Letras português/inglês, com proficiência em espanhol, italiano e latim. Atualmente é Professora Pesquisadora e PNPDCAPES do Programa de Doutorado e Mestrado em Direito Empresarial e Cidadania do Centro Universitário Curitiba UNICURITIBA; Membro da Comissão Consultiva da OIT e Gerente voluntária de Projetos da ONU Mulheres/Meninas.

2 Doutor em Direito das Relações Sociais pela Universidade Federal do Paraná (2002). Mestre em Direito Privado pela Universidade Federal do Paraná (1995). Diplôme Supérieur de I'Université - Droit du Travail \& Sécurité Sociale pela Université Panthéon-Assas/Paris II (1998). Juiz Titular da 9a Vara do Trabalho de Curitiba. Professor Permanente do Programa de Mestrado em Direito Empresarial e Cidadania do UNICURITIBA. Realizou estágio Pós-Doutoral na Universidade de Coimbra (2016-2017).

${ }^{3}$ Advogada trabalhista atuante, com parceria no escritório OSA - Oliveira Sociedade de Advogados em Pinhais/PR, Advogada contratada no escritório modelo do NPJ - Núcleo de Prática Jurídica UNICURITIBA em Curitiba/PR, autora do artigo "LER/DORT e o Trabalho Bancário" (2010) e coautora do artigo "Discriminação do Trabalhador Homoafetivo" (2012). Pós-Graduada em Direito do Trabalho no UNICURITIBA, autora do artigo "A Síndrome de Burnout nos Trabalhadores Bancários" (2014). Pós-Graduada em Direito Previdenciário, no UNICURITIBA. 
perspectiva pericial mais humana em prol da dignidade como alicerce do direito humano e fundamental de quem passa por este infortúnio, situação em que prejudica não só o empregado, mas como também sua família e refletindo na sociedade como um todo. Explanarse-á, por fim, a quem cabe a responsabilidade pelo pagamento de salário do empregado afastado para tratamento de saúde decorrente da síndrome de burnout a partir da suspensão do benefício previdenciário pelo fato do perito do INSS atestar pela sua aptidão, mesmo contrariando o diagnóstico do médico particular e da empresa.

Palavras-chave: Síndrome de Burnout, Perícia Técnica, Limbo Jurídico Previdenciário e Trabalhista, Responsabilidade Civil e Dignidade da Pessoa Humana.

\begin{abstract}
:
According to the Statistical Yearbook of work accidents, mental and behavioural disorders already occupies the third place in the sum to aid disease benefits, being these the diseases that most kept workers away from their jobs in 2011. In this context, we highlight the insured of the INSS affected with some kind of mental disorder, as the "professional exhaustion Syndrome"- Burnout Syndrome - which means, according to the researchers, "burns to exhaustion." In this sense, it is known that the role of the expert evidence for the observation of the disease and the granting of pension benefits for work disabilities in judgment is of paramount importance. With this report is that the insured will be released, or not, to return to his work, regardless of their ability to effectively work. Not always, the company considers him fit to work when faced with the pension labor legal limbo for being without benefits and salary by the suspension of payment due to the release of the expert, as well as to the likely inability configured by the employer. Will prove thus, the understanding of doctrine and jurisprudence, in search of a plausible answer to this issue, which emerges from a globalized society and technologically overwhelmed. However, without experts in favour of human dignity as a cornerstone of the human right and fundamental of who goes through this unfortunate situation, which harms not only the employee, but also his family and reflects on society as a whole. And will explains, finally, who is the responsible for paying the salary of the employee away for health treatment, arising from the suspension of the pension benefit that the INSS expert testifies to his ability, even contrary to the diagnosis of the personal physician and the company of the burnout syndrome.
\end{abstract}

Keywords: Burnout Syndrome, Technical Expertise, Legal Limbo Labour and Pension, Civil Responsibility and Human Dignity.

\title{
1 INTRODUÇÃO
}

Pesquisas têm demonstrado que o trabalho pericial é realizado de forma precária e superficial no atendimento ao público, pois com a sempre crescente necessidade de seus usuários, os resultados são insatisfatórios, ocasionando a consequente suspensão de benefícios, o que causa prejuízo manifesto aos segurados/trabalhadores e a diminuição de custos à máquina pública, além de, 
em muitos casos, se equivocar no diagnóstico devido à falta de conhecimento específico no assunto.

Neste contexto, destaca-se maior relevância os segurados do INSS acometidos com alguma espécie de transtorno mental, como a "Síndrome do Esgotamento Profissional" - Síndrome de Burnout - que, segundo pesquisadores, significa "queimar até a exaustão". A expressão vem do inglês e indica o colapso que sobrevém após a utilização de toda a energia disponível, sucede de um processo de estresse ocupacional, representando um estado físico de esgotamento, no qual o sujeito perde o sentido da sua relação com o trabalho.

Segundo o Anuário Estatístico de Acidentes de Trabalho, os transtornos mentais e comportamentais já ocupam o terceiro lugar em quantidade de concessões de auxílio doença acidentários, sendo estas as moléstias que mais afastaram os trabalhadores em $2011 .{ }^{1}$

Sobreleva notar, nesta perspectiva, como fator determinante em temas recorrentes que acabam por gerar reflexos em diversas questões da atualidade, como o aumento de segurados em situação de "limbo previdenciário/trabalhista", por conta de trabalhadores sem benefício e sem salário, devido à ausência de norma específica que estabeleça a responsabilidade ao pagamento das pessoas acometidas por esta doença mental decorrente do trabalho, em um liame com assuntos como aqueles relativos aos efeitos de um capital globalizado, aos avanços tecnológicos na sociedade moderna, aos ditames do neoliberalismo e à crescente individualização das pessoas no seio social.

A escolha do tema decorre especificamente pelo relevante aumento de trabalhadores acometidos pela moléstia e por estarem diretamente propensos

\footnotetext{
${ }^{1}$ De acordo com o diretor do Departamento de Políticas de Saúde e Segurança Ocupacional (DPSSO), Cid Pimentel, toda profissão apresenta um determinado grau de estresse. [...] A rotina vivida pelos trabalhadores brasileiros é, segundo Pimentel, outro agravante. "A pessoa acorda, vai trabalhar, volta para casa, assiste televisão e vai dormir, muitas vezes com a ajuda de medicamentos. Isso é altamente estressante", [...] Cid Pimentel, que também é psiquiatra e pesquisador em Saúde Pública, conta que viu de perto a construção da laborterapia, hoje chamada de terapia ocupacional. "Eu presenciei o esforço feito para transformar o trabalho em atividade terapêutica", relembra o diretor do DPSSO. "No entanto, o trabalho em escala, em condições insalubres e a recompensa insatisfatória são fatores que podem deflagrar a doença", acrescenta. Disponível em: htttp://www.previdencia.gov.br/2012/03/transtornosmentais trabalhoemescalacondicoesinsalubreserecompensainsatisfatoriapodemsercausas/> Ministério da Previdência Social. Acesso em 06 dez. 2015.
} 
a situações decorrentes de estresse, devido ao ambiente laboral em que estão inseridos, com intensa responsabilidade, aceleração do ritmo de trabalho, tecnologia da informação, cobrança excessiva pelo cumprimento das metas e 0 assédio moral, vindo a serem afastados sem perspectiva de retorno devido à incapacidade, porém, nem sempre sendo compreendidos nesta situação, pois, mesmo liberados pelo perito do INSS, o médico da empresa o considera incapacitado para o trabalho.

A realização deste estudo tem por objetivo enfrentar a seguinte problemática: "A quem cabe a responsabilidade pelo pagamento de salário do empregado afastado para tratamento de saúde decorrente de doença ocupacional (Síndrome de Burnout) a partir da suspensão do benefício previdenciário pelo fato do perito do INSS atestar pela sua aptidão, mesmo contrariando o diagnóstico do médico particular e da empresa?".

Para este fim, buscar-se-á respostas através de pesquisas bibliográficas de renomados autores, a exemplo de "José Antonio Savaris, Anderson Schreiber, Sebastião Geraldo de Oliveira, Rui Stoco e Marco Aurélio Marsiglia Treviso", bem como de pesquisa jurisprudencial de Tribunais relacionados ao tema (TRT/TRF/TNU).

De início, demonstrar-se-ão os aspectos relevantes quanto ao direito do segurado trabalhador à percepção do benefício previdenciário quando acometido por uma doença incapacitante, passando pela importante abordagem da Síndrome de Burnout e seu enquadramento como doença ocupacional (sintomas, características e causas), para verificar a possibilidade do estabelecimento de uma ligação entre a síndrome e o trabalho, abrangendo explicações não somente em relação ao nexo causal específico, mas ao aspecto da concausalidade.

Em seguida, será explanado uma breve descrição sobre a responsabilidade civil quanto ao pagamento do salário/benefício aos trabalhadores acometidos pela Síndrome de Burnout quando liberados para o trabalho pelo INSS, mesmo estando incapacitados para a função pela qual foram contratados, segundo a empresa e o médico do trabalho, deixando o trabalhador no limbo jurídico (sem benefício e sem salário). 
Por fim, demonstrar-se-á o entendimento jurisprudencial tanto pelos Tribunais Regionais do Trabalho, quanto pela Justiça Federal, bem como, a demonstração de prováveis soluções para o caso, dentro do que foi apresentado no decorrer do trabalho.

\section{BENEFÍCIO PREVIDENCIÁRIO - DOENÇA OCUPACIONAL}

No Brasil são os trabalhadores, empresas, o Estado, em suma, a sociedade de maneira geral, que custeiam o regime previdenciário através de Contribuições Sociais, como INSS, PIS, Cofins, dentre outros (art. 201, caput, $\mathrm{CF} / 88$ ), cumprindo ao Estado garantir a sustentação do regime previdenciário. Eventuais insuficiências financeiras deverão ser cobertas pelo Poder Público (art. 16, parágrafo único, Lei 8.212/1991).

O RGPS - Regime Geral de Previdência Social - abrange todos os trabalhadores da iniciativa privada, desde empregados (regidos pela CLT), aprendizes, temporários e autônomos em geral, até empresários titulares de firmas individuais ou sócios gestores, trabalhadores avulsos, pequenos produtores rurais, etc e a Lei 8.213/91 - Plano de Benefícios da Previdência Social - prescreve a filiação compulsória e automática para os segurados obrigatórios e é gerido pelo INSS - Instituto Nacional do Seguro Social.

No caso de acidente de trabalho, importa salientar que há obrigação na contribuição das empresas (art. 22, da Lei 8.212/91), e o FAP - Fator Acidentário de Prevenção está previsto no art. 202-A, do Decreto 3.048/99 sendo definindo como fonte de custeio para a cobertura de eventos advindos dos riscos ambientais do trabalho (acidentes e doenças do trabalho, assim como as aposentadorias especiais ).

Por oportuno, importa lembrar que a Previdência Social é um direito constitucional, um direito social fundamental do indivíduo ( $\mathrm{CF} / 88$, art. 6o), nos dizeres de Savaris "O sistema pelo qual o Estado e a sociedade protegem o indivíduo contra riscos que podem prejudicar sua saúde, impedir seu desenvolvimento ou diminuir sua capacidade para o trabalho" (SAVARIS, 2014, p. 29), sendo chamada pela Constituição de Seguridade Social (art. 194). A Seguridade Social é, então, "o modelo de proteção social definido pela 
Constituição. Ela se destina a assegurar os direitos dos indivíduos à saúde, assistência social e previdência social”.(SAVARIS, 2014, p. 29)

O artigo 59 da Lei $n^{\circ}$ 8.213/91 dispõe em seu caput:

O auxílio-doença será devido ao segurado que, havendo cumprido, quando for o caso, o período de carência exigido nesta Lei, ficar incapacitado para o seu trabalho ou para a sua atividade habitual por mais de 15 (quinze) dias consecutivos.

Por sua vez, no artigo 86, dispõe que por auxílio-acidente ${ }^{2}$, entende-se ser um benefício previdenciário pago mensalmente ao segurado acidentado como forma de indenização, sem caráter substitutivo do salário, pois é recebido cumulativamente com o mesmo, quando, após a consolidação das lesões decorrente do acidente de qualquer natureza - e não somente de acidente de trabalho - resultam sequelas que impliquem redução da capacidade para 0 trabalho que atualmente exercia. (KRAVCHYCHN, 2013, p. 560)

Diferencia-se do auxílio-doença na medida em que este é devido enquanto o segurado estiver incapaz, temporariamente, para o trabalho, enquanto o auxílio-acidente, por seu turno, é devido após a consolidação das lesões ou perturbações funcionais de que foi vítima o acidentado, ou seja, após a "alta médica", não sendo percebido juntamente com o auxílio-doença, mas somente após a cessação deste último - Lei do RGPS, art. 86, $§ 2^{\circ}$.

O benefício em questão passou a ser devido em relação a acidentes de qualquer natureza (e não só acidente de trabalho) a partir da redação conferida na Lei no 9.032/1995, não se aplicando a acidentes não ligados ao trabalho ocorridos até 29.04.1995.

É devido o benefício a partir da data cuja perícia médica do INSS concluir - após a consolidação das lesões decorrentes de acidente de trabalho ou não, haver no segurado sequelas definitivas enquadradas nas situações previstas no Anexo III do Regulamento da Previdência Social, ensejando redução da capacidade funcional, considerando-se, pra este fim, a atividade

\footnotetext{
20 art. 19, da Lei 8.213/91, define Acidente do trabalho como sendo o fato que ocorre no exercício do trabalho a serviço da empresa, que provoca lesão corporal ou perturbação funcional, podendo causar morte, perda ou redução permanente ou temporária, da capacidade para o trabalho. $\mathrm{O}$ art. 20 da referida Lei considera como acidente algumas entidades mórbidas, quais sejam a doença profissional e a doença do trabalho. São fatores debilitantes que dificultam ou impedem o exercício normal das funções, de modo a levar o trabalhador a perder ou reduzir sua capacidade de trabalho, temporária ou permanentemente.
} 
realizada na época do acidente $\left(\S 8^{\circ}\right.$ do art. 104 , inserido pelo Decreto $\mathrm{n}^{\circ}$ 4.729, de 09.06.2003).

Saliente-se que, para a Previdência Social, o dano que enseja auxílioacidente é o que acarreta perda ou redução na capacidade de trabalho (redução esta, qualitativa ou quantitativa), sem caracterizar a invalidez permanente para todo e qualquer trabalho.

O auxílio-acidente deixou de ser vitalício e passou a integrar o salário de contribuição para fins de cálculo do salário de benefício de qualquer aposentadoria e sua suspensão depende do resultado de perícia médica feita periodicamente para sua manutenção, encerrando-se com a morte do segurado ou com o retorno de sua capacidade laboral.

Portanto, em caso excepcional, constatando-se que a doença não incluída na relação resultou das condições especiais em que o trabalho é executado e com ele se relaciona diretamente, deve a Previdência Social considerá-la acidente de trabalho, necessário para tanto, a caracterização da doença através de perícia e também análise do Nexo Técnico Epidemiológico Previdenciário (NTEP). ${ }^{3} 4$

Subentende-se, entretanto, que é preciso constatar se há o Nexo Epidemiológico Previdenciário com a atividade exercida conforme demonstrado

3 AUXÍLIO-ACIDENTE: Previdência acaba com subnotificação de acidentes de trabalho. Ministério da Previdência Social, Brasília, 23 dez. 2008. Disponível em: $<$ http://www.previdencia.gov.br/noticias/ auxilio-acidente-previdencia-acaba-comsubnotificacao-de-acidentes-de-trabalho/>. Acesso em: 31 mar. 2014.

${ }^{4}$ Cabível, aqui, a seguinte transcrição, retirada do Decreto no 3.048 , de 06 de maio de 1999: "Art. 337. O acidente do trabalho será caracterizado tecnicamente pela perícia médica do INSS, mediante a identificação do nexo entre o trabalho e o agravo. (Redação dada pelo Decreto no 6.042, de 2007). [...]. $\S 3^{\circ}$ Considera-se estabelecido o nexo entre 0 trabalho e 0 agravo quando se verificar nexo técnico epidemiológico entre a atividade da empresa e a entidade mórbida motivadora da incapacidade, elencada na Classificação Internacional de Doenças CID em conformidade com o disposto na Lista C do Anexo II deste Regulamento. (Redação dada pelo Decreto $n^{\circ}$ 6.957, de 2009). § 4ํ Para os fins deste artigo, considera-se agravo a lesão, doença, transtorno de saúde, distúrbio, disfunção ou síndrome de evolução aguda, subaguda ou crônica, de natureza clínica ou subclínica, inclusive morte, independentemente do tempo de latência. (Incluído pelo Decreto № 6.042, de 2007). § 5 Reconhecidos pela perícia médica do INSS a incapacidade para o trabalho e o nexo entre o trabalho e o agravo, na forma do § 3o, serão devidas as prestações acidentárias a que o beneficiário tenha direito. (Incluído pelo Decreto $n^{\circ} 6.042$, de 2007). § 6ㅇ A perícia médica do INSS deixará de aplicar o disposto no § 3 o quando demonstrada a inexistência de nexo entre o trabalho e o agravo, sem prejuízo do disposto nos $\S \S 70$ e 12. (Redação dada pelo Decreto oㅜ 6.939, de 2009). [...]." (BRASIL. Decreto $n^{\circ}$ 3.048, de 06 de maio de 1999. Aprova o Regulamento da Previdência Social, e dá outras providências. Diário Oficial [da] República Federativa do Brasil, Brasília, DF, 12 maio 1999 (republ.). Disponível em: <http://www.planalto.gov.br/ccivil_03/ decreto/D3048.htm>. Acesso em: 13 abr. 2014. 
anteriormente, sendo este parte indissociável do diagnóstico que se fundamenta em uma boa anamnese ocupacional e em relatórios de profissionais que conhecem a situação de trabalho.

É de primordial importância entender que não se deve confundir "incapacidade" com "impedimento" ou "impossibilidade" absoluta para o trabalho, assim como não se pode confundir "doença" com incapacidade, no sentido de que o fato de alguém ser portador de uma patologia ou lesão, por si só, não lhe assegura o direito ao benefício por incapacidade, a identificação, pelo perito, de que o segurado está exercendo atividade laboral, não deve implicar a conclusão de que ele não se encontre incapaz para o trabalho, em termos previdenciários.

Não se pode olvidar que há exigência de comprovação de que a moléstia impede, total ou parcialmente, o exercício de atividade remunerada, de forma definitiva ou temporária.

Assim, imperioso se torna esclarecer quando o segurado/trabalhador tem direito ao benefício auxilio doença ou acidente ao se encontrar acometido por uma doença incapacitante para o trabalho, em especial o transtorno mental conhecido como Síndrome de Burnout.

Burnout significa desgaste, ficar exausto por se esforçar excessivamente, com a finalidade de responder a constantes solicitações de energia, força ou recursos, sendo uma das consequências mais marcantes do estresse profissional. Segundo Rodrigues, Campos e Valente, a aludida síndrome foi caracterizada por Maslach da seguinte forma: "exaustão emocional, despersonalização e diminuição da realização profissional." (PERREWÉ, 2011, p. 140).

Diferentemente de outros países, onde prosperam muitas pesquisas e estudos sobre a Burnout, mas que, até o momento, não possuem uma lei que contemple esta síndrome como uma doença laboral, no Brasil, o Decreto no 3048/99 (que regulamenta a Previdência Social), ao tratar em seu Anexo II dos Agentes Patogênicos causadores de Doenças Profissionais ou do Trabalho, aponta a Síndrome de Burnout ou Síndrome do Esgotamento Profissional como um agente etiológico ou como um dos fatores de risco de natureza 
ocupacional, tendo como causa o ritmo de trabalho penoso (Z-56.33). (MENDES, 2014, p. 17)

O Ministério da Saúde também tem aprovada a "Lista de Doenças Relacionadas com o Trabalho", editada pela Portaria n 1.339/GM, de 18 de novembro de 1999, na qual consta a Síndrome de Burnout como umas das hipóteses equiparáveis a acidente de trabalho (Z-73.0). ${ }^{5}$

Destaca-se, assim, que a Síndrome de Burnout é hipótese de acidente do trabalho, conforme se infere do Anexo II do referido Decreto no 3.048/99 no quadro transtornos mentais e do comportamento relacionados com o trabalho (Grupo V, da CID-10). 6

Depois destas considerações, importante questão tem sido debatida quanto a prova para o enquadramento da doença como acidente de trabalho ou doença ocupacional, a tão perversa pericia médica, a qual é de primordial importância para se confirmar 0 afastamento e receber 0 benefício previdenciário no período em que se mantiver a incapacidade laboral.

\section{PROVA TÉCNICA - PERÍCIA MÉDICA PREVIDENCIÁRIA E TRABALHISTA}

A incapacidade para o trabalho necessita ser comprovada pelo que se conhece por prova técnica, realizada pelo perito consubstanciada em prova pericial, a qual deve ser compreendida à luz da realidade de vida do segurado.

Neste sentido, Gouveia (2012, p. 177) se posiciona:

\footnotetext{
${ }^{5}$ Manual de procedimentos para os serviços de saúde, Capítulo 10 - Transtornos Mentais e do Comportamento Relacionados ao Trabalho (Grupo V da CID-10). 10.3 Lista de Transtornos Mentais e do Comportamento Relacionados ao Trabalho, de acordo com a Portaria oㅡ 1.339/1999: 10.3.12 Sensação de Estar Acabado (Síndrome de Burn-out ou Síndrome do Esgotamento Profissional) (Z73.0). (BRASIL. Ministério da Saúde. Doenças relacionadas ao trabalho: Manual de procedimentos para os serviços de saúde. Brasília, 2001. Disponível em: $<$ http://dtr2001.saude.gov.br/editora/produtos/livros/pdf/ 02_0388_M1.pdf>. Acesso em: 20 nov. 2013.

6 LISTA B do ANEXO II do Decreto $n^{\circ}$ 3.048/1999: "TRANSTORNOS MENTAIS E DO COMPORTAMENTO RELACIONADOS COM O TRABALHO (Grupo V da CID-10) [...] XII Sensação de Estar Acabado ("Síndrome de Burn out", "Síndrome do Esgotamento Profissional") (Z73.0). 1. Ritmo de trabalho penoso (Z56.3). 2. Outras dificuldades físicas e mentais relacionadas com o trabalho (Z56.6)." BRASIL. Decreto $n^{\circ} 3.048$, de 06 de maio de 1999. Aprova o Regulamento da Previdência Social, e dá outras providências. Diário Oficial [da] República Federativa do Brasil, Brasília, DF, 12 maio 1999 (republ.). Disponível em: <http://www.planalto.gov.br/ccivil_03/decreto/D3048.htm>. Acesso em: 13 abr. 2014.
} 
Desse modo, prova nada mais é do que o conjunto de elementos que leva ao convencimento da certeza de um fato, dessa sorte, às partes incube a exposição e comprovação dos fatos, já que o Juiz deve, à partir da comprovação dos fatos, dizer o direito - iura novit curia.

Interessante registrar que há legislação específica quanto aos meios de prova disponíveis, sendo hábeis para comprovar a incapacidade e levar ao convencimento do juiz. ${ }^{7}$

Segundo Savaris (2014, p. 181), medir a importância do direito à prova em matéria previdenciária pressupõe duas elementares observações, quais sejam:

Primeira, o objeto de estudo hospeda a convergência de dois direitos constitucionais fundamentais: o direito processual de produzir prova licita e o direito material à Previdência Social. Se o direito de produzir prova é irradiação do devido processo legal e por seu conteúdo intrínseco já manifesta superior dignidade, quando as provas se faz instrumento para a satisfação de um direito fundamental intimamente ligado à dignidade da pessoa humana ela se demonstra de importância singular. É um direito fundamental como meio de satisfação de um bem da vida também fundamental. A missão da prova não poderia ser então mais nobre. $E$ a violação deste direito, por consequência, é algo extremamente gravoso.

Segunda observação: a atribuição de um direito previdenciário pressupõe laboriosa tarefa de exames de fatos, bastando referir que imensa maioria de ações em que se pretende a concessão de uma prestação previdenciária veicula discussão de natureza fática: a incapacidade para o trabalho [...].

Sabe-se que em sede de Juizado Especial Federal, incumbe à Administração a produção de prova, de acordo com 0 art. 11, da Lei 10.259/2001, superando a tradicional doutrina de que cabe à parte que alega produzi-la, nos termos do art. 333, do CPC.

Entende-se por prova pericial, o meio pelo qual se obtém um laudo que contém declaração de ciência e a afirmação de juízo de valor a respeito de fato litigioso realizadas por especialista em determinado ramo do conhecimento humano, estando legalmente disciplinada no Código de Processo Civil , artigos 420 e 439, as quais se aplicam também em matéria previdenciária.(GOUVEIA, 2012, p. 183).

7 O Código de Processo Civil Brasileiro dispõe como meios de prova o depoimento pessoal (arts. 342 a 347), exibição de documentos ou coisa (arts. 355 a 363), prova documental (arts. 364 a 399), confissão (arts. 348 a 354), prova testemunhal (arts. 400 a 419), inspeção judicial (arts. 440 a 443) e prova pericial (arts. 420 a 439). BRASIL, Lei no 13105 de 16 de março de 2015, Código de Processo Civil, DF, Disponível em: <http:// www.planalto.gov.br/ ccivil _03 I_Ato2015-2018/2015/Lei/L13105.htm> Acesso em: 23 fev. 2016. 
O laudo médico-pericial é peça fundamental, portanto, é documento médico legal decisivo, tanto na via administrativa, recursal, ou em juízo. Nele deve estar contida toda a condição técnica e ética do médico-perito, e, portanto, sua confecção deve ser sempre com a maior acurácia e dedicação (INSS, 1993).

Importante ressaltar ser regra que o perito deve ser especialista na doença incapacitante, podendo até ser anulada a sentença em caso ficar constatado que o laudo foi apresentado por médico de outra especialidade (SERAU JR, 2012, p. 240).

Relevante questão é quanto a outras formas de se constatar a doença, além da documental e pericial, como por exemplo através da oitiva da parte em audiência de instrução (prova oral), podendo, assim, complementar o laudo por este meio de prova, também pelo depoimento técnico do perito e assistente, atendendo-se 0 que dispõe 0 art. 421, $2^{\circ}$, do CPC.8, principalmente quando houver dúvidas quanto aos documentos já juntados, devendo-se evitar, entretanto, o constrangimento do segurado, atentando-se para a preservação da sua dignidade.

Nota-se, assim, que a junção de outras provas, como a oral e pericial, dentre outras, transformam a perícia em um procedimento menos formal, mais célere, prestigiando o princípio da oralidade, celeridade, livre convencimento do julgador e imediação, bem como disponibilizando a oportunidade do segurado/trabalhador demonstrar a realidade dos fatos alegados na inicial ou pedido administrativo ao comparecer pessoalmente perante ao juiz, bem como, ao ser registrado em audiência, na presença do procurador, os apontamentos , impugnações e aclaramentos pelo perito e assistente técnico. (GOUVEIA, 2012, p. 160).

Lembrando que, este tipo de perícia (prova pericial oral) também privilegia o Princípio da Máxima Eficiência dos Meios Probatórios e os

\footnotetext{
${ }^{8} \mathrm{CPC}$, art. $421, \S 2^{\circ}$. Quando a natureza do fato o permitir, a perícia poderá consistir apenas na inquirição pelo juiz do perito e dos assistentes, por ocasião da audiência de instrução e julgamento a respeito das coisas que houverem informalmente examinado ou avaliado. (Redação dada pela Lei no 8.455, de 24.8.1992).Disponível em: http://www.planalto.gov.br/ccivil_03/leis/L5869compilada.htm. Acesso em 21.10.2015.
} 
Princípios do Devido Processo Legal ${ }^{9}$, Direito Fundamental à Prova, Contraditório, Publicidade e fundamentação, beneficiando-se, inclusive com depoimento do médico particular em que o segurado mantém o tratamento desde o início da patologia, de testemunhas e das próprias partes, ampliando o acervo informativo a ser considerado pelo expert e pelo juiz da causa, estendendo-se às peculiaridades do caso concreto.(GOUVEIA, 2012, p. 238).

Nesta mesma linha de raciocínio, Savaris (2014, p. 105) esclarece:

Ainda que em doutrina o juiz não esteja adstrito ao laudo pericial, na pratica sucede o contrário, e as autoridades julgam, em geral, de acordo com o parecer dos peritos nomeados. O quotidiano então serve de alerta aos médicos peritos para que promovam uma investigação mais completa possível, certo também de que a grande quantidade de demandas judiciais acaba induzindo o juiz a um raciocínio de simples homologação da conclusão pericial e ainda, com tendência de confirmação por seus próprios fundamentos as sentenças atacadas pela via recursal.

Entretanto, outro relevante ponto a ser observado é a combinação da perícia médica com a realização de vistoria no ambiente de trabalho quando se tratar de doença profissional ou acidente de trabalho, haja vista o dever da comprovação do nexo causal nestes casos para percebimento do auxílio acidente ou aposentadoria por invalidez decorrente. ${ }^{10}$

Como visto anteriormente, a concessão do auxílio-doença está sujeita à comprovação da incapacidade laborativa em exame realizado pela perícia médica da Previdência Social, sendo imprescindível a produção de prova pericial por médico que tenha domínio sobre a patologia em discussão, esta conhecida por prova técnica, não sendo possível ao órgão julgador decidir sem permitir a apresentação do resultado deste exame pelo expert, possibilitando às partes, inclusive, formular quesitos a serem respondidos neste momento pelo perito (KRAVCHYCHYN, 2013, p. 322).

\footnotetext{
${ }^{9}$ Art. 5은, LIV e LV, da Constituição Federal de 1988, disponível em http://ww.planalto.gov.br/ ccivil_03/Constituicao/Constituicao.htm>. Acesso em 23 fev. 2016.

10 DŌENÇA AGRAVADA PELO AMBIENTE DE TRABALHO. SÍNDROME DE BURNOUT. A doença acometida pelo reclamante pode ter várias origens e fatores desencadeantes diversos, porém, no presente caso, restou comprovado que a doença foi decorrente das condições laborais (Síndrome de Burnout). A prova oral produzida demonstra, em conjunto com a prova documental acostada aos autos, que o ambiente de trabalho era inadequado ao labor diário e, nos termos da perícia feita, esta condição foi causa desencadeadora da doença acometida pelo reclamante. Recurso conhecido e não provido. I -(TRT-10 - RO: 1304200800710000 DF 01304-2008-007-10-00-0 RO, Relator: Desembargador Alexandre Nery de Oliveira, Data de Julgamento: 25/07/2012, 2ª Turma, Data de Publicação: 17/08/2012 no DEJT).(g.n.)
} 
Esclarece-se, por oportuno, que a pericia médica do INSS tem como objetivo fundamental a emissão de laudos/pareceres conclusivos na avaliação da incapacidade laboral, sejam dos benefícios tipicamente previdenciário ou benefícios assistenciais por incapacidade, sendo que, deve este trabalho ser feito por profissional pertencente à categoria funcional-perito, do quadro de pessoal do INSS, o qual, em regra, deve possuir treinamento adequado para exercer suas funções, ou por profissionais autorizados sob a forma de credenciamento ou de convênio.(GOUVEIA, 2012, p. 13).

Ainda sobre a parte técnica, vale dizer que as conclusões médico periciais prevalecem para efeito de concessão e manutenção dos benefícios previdenciários e assistenciais por incapacidade, entretanto, é fundamental demonstrar que existem procedimentos a serem seguidos na realização destas pericias, tanto no âmbito das empresas, quanto no INSS, bem como em sede de pericia judicial, impondo ao profissional da Medicina observar ditames do Código de Ética da categoria, e especialmente em relação ao tema a Resolução oํ 1.488/1998 do Conselho Federal de Medicinai é que dispõe sobre as normas especificas de atendimento a trabalhadores (KRAVCHYCHYN, 2013, p.325) estabelecendo parâmetros sobre a forma que a perícia deve considerar, incluindo estudo psicossocial e as atribuições e deveres deste expert. ${ }^{11}$

Denota-se, em suma, pelos dispositivos elencados na aludida Norma Legal que a perícia realizada em juízo não difere em termos de deveres do profissional que o realiza, daquele que devam ser realizadas por médicos de empresas ou do órgão previdenciário (art. 10 inciso II, da resolução 1.488/1998 do Conselho Federal de Medicina), seja quanto aos aspectos éticoprofissionais.( KRAVCHYCHYN, 2013, p.325).

Ressalta-se, no entanto, que para uma adequada analise do possível nexo de causalidade, torna-se necessário, em regra, vistoriar o local de trabalho, afim de observar os agentes que possam ter ocasionado a patologia do segurado (art. $2^{\circ}$ inciso II da Resolução), não sendo crível que um perito possa, sem sombra de dúvidas, avaliar a relação de causalidade com o labor

11 Resolução no 1.488/1998 do Conselho Federal de Medicina, disponível em: http://www.portalmedico.org.br/resolucoes/cfm/1998/1488_1998.htm Acesso em 20 out 2015. 
sem saber exatamente de que forma a atividade laboral era cumprida. (KRAVCHYCHYN, 2013, p. 325).

Ainda, observa-se pela Resolução que o exame pericial não se esgota no exame clinico sobre a situação atual do segurado, devendo necessariamente ser apreciado a histórica clínica e ocupacional, item considerado decisivo para qualquer diagnostico de nexo de causalidade.

A perícia médica administrativa está prevista na Lei 9.784/99 (Lei do Processo Administrativo Federal), devendo, assim, se submeter àqueles ditames legais e, observar, dentre estes os princípios ali estabelecidos, lembrando que é obrigatória a fundamentação na decisão, sob pena de violar princípios constitucionais e legais.

Na Justiça do Trabalho o problema é tão acintoso que o Comitê Nacional do Programa Trabalho Seguro do TST/CSJT elaborou Diretrizes sobre a prova pericial em acidentes de trabalho e doenças ocupacionais e as Propostas de enunciados sobre pericias judiciais em acidente de trabalho e doenças ocupacionais. $^{12}$

A perícia judicial, assim, deve corresponder ao que dela se espera: um aporte especializado que pressupõe um conhecimento técnico/cientifico específico que contribua no sentido de esclarecer algum ponto considerável imprescindível para a solução do processo judicial, portanto, esta é tida como rainha das provas.

No que diz respeito à falta de qualidade das pericias, esclarece-se que existem algumas recomendações de Fóruns Previdenciários Interinstitucionais organizados pela Coordenação do Juizados do TRF, dentre os quais se destacam duas delas, quais sejam:

O Fórum recomenda a adoção de medidas para a melhoria da qualidade das pericias na Justiça federal" (Enunciado $n^{\circ} 8$ - Fórum Int. Prev-PR).

Recomenda-se a adoção de medidas para a melhoria da qualidade das pericias na Justiça Federal, sugerindo que os médicos peritos, quando realizada pericia em audiência, disponham de tempo suficiente para resposta fundamentada aos quesitos e que, preferencialmente, a perícia seja realizada por médico especialista na patologia apresentada pelo autor" (Recomendação nำ3 do Fórum Internacional Previdenciário-SC) (KRAVCHYCHYN, 2013, p. 325).

\footnotetext{
12 Diretrizes sobre prova pericial em acidentes de trabalho e doenças ocupacionais. Comitê Gestor Nacional do Programa Trabalho Seguro. Disponível em: <http://www .trt18 .jus.br/portal/arquivos/2015/08/diretrizes.pdf>. Acesso em 25 out. 2015.
} 
Relevante questão, ainda, é em muitos casos em relação à ausência de análise psicossocial do segurado/trabalhador quando se depara com o perito médico, análise esta que deveria ser levado em consideração aspectos como: condições sociais do trabalhador, grau de instrução (social e educacional) e idade, o que não se observa em todos os relatórios apresentados pelos experts.

Diante das considerações legais e entendimentos doutrinários entendese que a perícia judicial, em caso de doença e acidente de trabalho, deve ser realizada considerando as particularidades de cada situação fática, utilizandose de profissional imbuído da competência necessária para a verificação do nexo causal, a existência de dano e sua extensão, a incapacidade ou capacidade residual de trabalho da vítima, o percentual de invalidez ou invalidez total e a possibilidade de readaptação em alguma outra função na empresa. ${ }^{13}$

Verifica-se, assim, que a incapacidade para o trabalho não pode ser identificada apenas a partir de uma perspectiva médica, devendo o juiz cientificar-se de tais circunstancias e, em caso de não terem sido objeto de exame pericial (laudo) considerar outras provas juntadas aos autos para firmar seu convencimento, de acordo com o disposto no artigo 436 do Código de Processo Civil.

$\mathrm{Na}$ verdade, a relevância que se atribui à atuação do perito no campo ético, humanístico e processual guarda nexo de causalidade com a concretização dos direitos metaindividuais dos segurados/trabalhadores e, por conseguinte, com o acesso efetivo à Justiça em busca da pretensão quanto ao percebimento do benefício previdenciário de caráter alimentar. De nada adiantaria os legitimados para receber benefício previdenciário preencherem os requisitos para tanto se faltar ao perito os conteúdos técnicos, humanísticos e profissionais adequados a rechaçar a pretensão requerida inicialmente.

Destarte, está nas mãos do perito a chave para fazer valer de forma efetiva os direitos metaindividuais dos segurados/trabalhadores. Isso exige

13 Revista RST no 306, dezembro/2014, Parte Geral, Artigo: Pericia Judicial na Justiça do Trabalho: Aspectos polêmicos. Carla Rita Bracchi Silveira. p. 114. 
uma visão mais ampla destes experts no que diz respeito à análise dos laudos periciais, que devem ser apreciados com ética e humanismo com vistas a assegurar o acesso à justiça por meio de um laudo justo e fundamentado, isso sem falar nos reflexos e nas repercussões socioeconômicas que estes resultados reproduzem na sociedade.

Neste ínterim, vislumbra-se a importância destes experts na aferição de valores éticos e morais depois da inserção na carreira para formarem laudos que serão julgados por juízes, os quais afetam diretamente a dignidade, a vida, a saúde, a segurança, a liberdade e o patrimônio das pessoas a que estarão submetidas diretamente destes resultados.

Na prática, porém, vislumbram-se peritos assoberbados de trabalhos e tendo que cumprir metas impostas pelo poder público em busca de "economizar" no orçamento à custa dos contribuintes ensejando uma quantidade enorme de indeferimentos de benefícios, proliferando, inclusive, médicos peritos acometidos pela Síndrome de Burnout, ou seja:

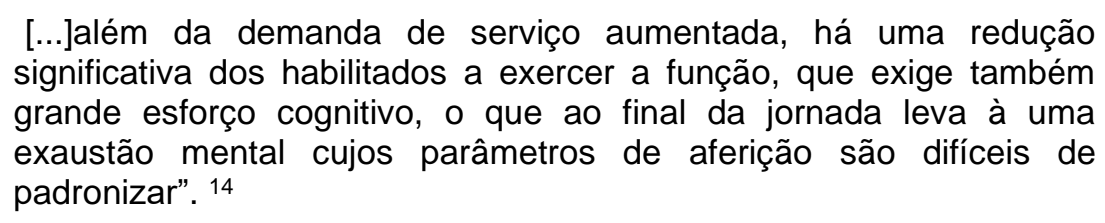

Em decorrência destes problemas tem-se intensificado a evasão de peritos com pedidos de aposentadorias e afastamentos, pois, conforme pesquisa em um blog médico "desde 01.01.2010 já perdeu-se 2.530 peritos do INSS a pedido ou aposentados, chegando ao índice de evasão de peritos em 1.15 ao dia ou 1.5/dia útil. ${ }^{\prime 15}$

$\mathrm{Na}$ mesma linha de raciocínio Mary Sandra Carlotto e outros, vislumbram o outro aspecto polemico em relação à incongruência entre o conhecimento médico e a realidade das fichas médicas quando se deparam com a Síndrome de Burnout. Frise-se:

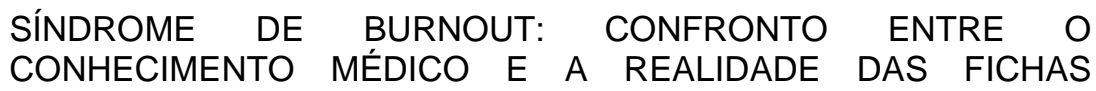

14 ELEMENTOS DE TECNOSTRESSE E SÍNDROME DE BURNOUT PRESENTES NO PROCESSO DE TRABALHO DO PERITO MÉDICO PREVIDENCIÁRIO. Rosimara Moraes Bonfim . Pós-Graduanda em Medicina do Trabalho - turma CENBRAP Governador ValadaresMG (Disponível em: http://peritomed.files.wordpress.com/2012/07/trabalho-de-conclusc3a3oburnout.pdf). Acesso em 05 out 2015.

15 EVASÃO DE PERITOS. No site estes dados é chamado de "Exonerômetro". Disponível em: http://www.perito.med.br/p/exonerometro.html . Acesso em: 06 out 2015. 


\begin{abstract}
MÉDICAS Jaqueline Brito Vidal Batista* Mary Sandra Carlotto Antônio Souto Coutinho e Lia Giraldo da Silva Augusto. RESUMO. A partir da ampliação de sua prática profissional, incluindo, além do ensino, atividades de cuidado para com o aluno e a missão de garantir a articulação entre a escola e a comunidade, o professor se tornou mais suscetível a desenvolver a Síndrome de Burnout, doença ocupacional contemplada pelo Ministério da Saúde desde 1999. Um dos responsáveis pelo seu diagnóstico institucional é a perícia médica. Dada a importância do diagnóstico correto da Síndrome de Burnout, esse estudo teve como objetivo investigar, através da aplicação de questionário e da consulta a fichas médicas, o conhecimento da perícia médica da Junta Médica Municipal da cidade de João Pessoa, PB, a respeito dessa síndrome. Os resultados apontaram o desconhecimento da legislação e da Síndrome de Burnout e a necessidade de uma intervenção de políticas públicas que proporcionem um maior preparo dos médicos peritos e uma melhor assistência à saúde mental do professor. Palavras-chave: Síndrome de Burnout; saúde mental; saúde do professor. ${ }^{16}$
\end{abstract}

Imprescindível, então, a formação peculiar e especifica de todos os peritos em geral, no tocante à prática dos direitos humanos, haja vista que 0 exercício diário da profissão requererá contato direta ou indiretamente com direitos e interesses que não podem ser examinados de forma desvinculada dessa visão humanística. Mormente quando o expert se depara com um volume excessivo de pericias, levando-os muitas vezes à exaustão mental.

Por fim, importa lembrar que o segurado/trabalhador adoentado, quando chega ao cumulo de propor uma ação na justiça federal (laboral ou previdenciária), já passou por uma intensa via crucis de exames, pedidos de benefícios previdenciários, demissão, falta de dinheiro e depressão por se sentir inútil perante a família e a sociedade. Este acúmulo de dissabores neste trabalhador - ser humano - afetando sobremaneira sua dignidade humana, preceito fundamental defendido no art. $1^{\circ}$ da $\mathrm{CF} / 88$.

\title{
4 LIMBO JURÍDICO - DECISÕES ANTAGÔNICAS ENTRE EMPRESA E INSS
}

Por limbo jurídico previdenciário entende-se que significa a ausência de salário e de benefício previdenciário ao segurado/trabalhador em razão de sua incapacidade laboral não reconhecida pelo perito médico, momento em que o

\footnotetext{
${ }^{16}$ BATISTA, Jaqueline Brito Vidal, e outros. Artigo. Síndrome de Burnout: confronto entre o conhecimento médico e a realidade das fichas médicas. Disponível em: http://www.scielo.br/scielo.php?script=sci_arttext\&pid=\$1413-73722011000300010. Acesso em: 27 nov 2015.
} 
beneficiário recebe alta para o trabalho e seu benefício é suspenso, sendo que, ao passar pelo exame médico da empresa é considerado inapto para o exercício de sua atividade.

Neste contexto deixa o INSS de conceder o benefício previdenciário a que teria direito em caso de incapacidade por entender estar apto para retornar ao trabalho e o empregador se nega a receber o trabalhador em razão de sua inaptidão para o labor, entendendo que este indivíduo deveria receber o beneficio previdenciário.

Vislumbra-se, assim, uma lamentável situação em que 0 trabalhador/segurado encontra-se à mercê da humilhação, sofre discriminações/preconceitos, passa a viver de favores de parentes e amigos, sem perspectiva de retorno ao trabalho em decorrência de uma doença que nem sempre é aceita pelo perito médico como incapacitante para o trabalho mesmo sem condições laborais para o retorno ao trabalho em vista de uma condição oriunda de um ambiente laboral hostil e inseguro (exaustão profissional - pavor pelo trabalho exercido).

Em particular a respeito do trabalhador/segurado acometido pela Síndrome de Burnout, destaca-se a falta de conhecimento dos próprios médicos da área psiquiátrica e/ou psicológica quando se deparam com a referida doença. ${ }^{17}$

Ressalta-se que, apesar de inexistir legislação específica sobre este tema, tem-se consolidado na jurisprudência trabalhista e previdenciária que é ilícita a conduta do empregador ao dispensar e/ou deixar de pagar salário ao trabalhador em situação de limbo jurídico, como se verá adiante.

Marco Aurélio M. Treviso (2012, p? ${ }^{18}$ tenta solucionar o problema do limbo jurídico através da concentração da competência para decisão da incapacidade do trabalhador diretamente à Justiça do Trabalho tendo em vista as divergências quanto ao laudo pericial entre as áreas previdenciária e

\footnotetext{
17 PERICIA MÉDICA_RELATO DE UMA SEGURADA. trabalhadora/segurada que registra seu "medo" e "frustração" em caso de o INSS suspender o beneficio previdenciário sem ter nenhuma condição de retorno ao trabalho, bem como, a humilhação sofrida em cada perícia em que precisa ser submetida para se manter afastada.(Disponível em:

http://www.assediados.com/2012/10/relato27impericiadapericia.HTML. Acesso em 10 set 2015.
} 
trabalhista, onde teria a participação das partes como assistente técnico na pericia médica, com um único laudo médico pericial.

Tem-se verificado a causa de prejuízo ao trabalhador/segurado, bem como, em alguns casos, à empresa por conta de resultados de aptidão ou inaptidão nos laudos periciais.

Os prejuízos vão desde a falta de pagamento por parte do INSS, o qual suspende o benefício do Segurado/trabalhador por atestar sua aptidão para o trabalho e, consequentemente ao retornar à empresa é declarado como incapacitado para exercer a atividade para a qual foi contratado pelo Médico da empresa, ainda, ao adentrar com ação trabalhista por esta negativa, é surpreendido pelo laudo na justiça do Trabalho de inaptidão em vista da incapacidade laboral.

Neste período em que se discute se tem ou não incapacidade para o trabalho o empregado fica sem receber tanto o benefício quanto o seu salário, em alguns casos, fica a empresa pagando o salário, mas com o funcionário afastado por conta da incapacidade constatada pelo médico do trabalho, exatamente para se evitar um acidente de trabalho.

Verifica-se, assim, o limbo jurídico em que as partes estarão em prejuízo, sem ter uma solução plausível para ser aplicada ao caso concreto, sendo o empregado a parte mais prejudicada, o qual fica sem receber salário ou beneficio previdenciário e tem sua dignidade violada, bem como ferido o direito ao mínimo existencial proveniente da nossa Constituição Federal ( Art.

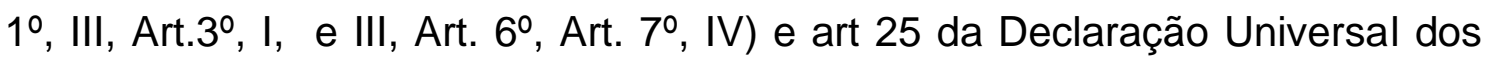
Direitos do Homem de 1948. ${ }^{19}$

Outro ponto destacado pelo r. doutrinador e jurista é quando a empresa se obriga a receber um empregado liberado pelo INSS, mas ainda incapacitado, podendo correr o risco de se provocar um acidente de trabalho por conta desta situação.

${ }^{19}$ Como ensina Tereza Negreiros o mínimo existencial está associado à manutenção de um padrão mínimo de vida o que equivale a associar a essencialidade à conservação da dignidade da pessoa humana. Afirma ainda a referida jurista que a essencialidade é considerada a linha de separação entre a humanidade e a desumanidade. Por tal razão por exemplo a Corte Constitucional da Alemanha como pontua Ricardo Lobo Torres define o mínimo existencial como sendo tudo aquilo que é necessário à existência digna. (TREVISO, 2012, p.65) 
Ressalta-se que o exame médico de retorno ao trabalho também é imposto por uma Norma Regimental, de № 7.4.3.3. a qual dispõe o seguinte: "No exame médico de retorno ao trabalho, deverá ser realizada no primeiro dia da volta ao trabalho de trabalhador ausente por período igual ou superior a 15 dias, por motivo de doença ou acidente, de natureza ocupacional ou não [...]".

Verifica-se, então, que o trabalhador, parte hipossuficiente no processo estará plenamente acobertado durante a fase em que estiver comprovadamente adoecido, deixando de ser violado em sua dignidade humana e mínimo existencial, pois, conforme bem destacado pelo renomado doutrinador, este individuo não poderá ficar a mercê da demora dos processos judiciais ou administrativos da previdência social, quando tem que primar pelas necessidades básicas para sobreviver, e, sem dinheiro para se sustentar e o sustento de seus dependentes pode até ser levado ao suicídio.

O Magistrado ainda destaca a importância de se estabelecer a competência para a Justiça do Trabalho para resolver a lide quanto à incapacidade laboral, haja vista a polêmica em relação aos diferentes resultados na perícia judicial (INSS/Trabalho/Empresa), sendo a relação oriunda de um contrato de trabalho. Sobre o assunto, leciona TREVISO (2012, p. 90):

\begin{abstract}
Agora, indaga-se: porque obrigar o trabalhador a ajuizar uma ação (contra o INSS) perante um ramo do Poder Judiciário e outra demanda (contra o empregador) em outro órgão do mesmo Poder quando o conflito envolve os dois lados da mesma moeda. Ora se o trabalhador está inserido num contrato de emprego, a responsabilidade pela garantia de pagamento dos valores mínimos necessários para se viver com dignidade, quando apto ao labor é do empregador; e, quando inapto, a responsabilidade é simplesmente transferida para o INSS, por força do mesmo vínculo jurídico base.

A resposta é absolutamente simples: deverá ser concedida ao trabalhador, a faculdade de, ao invés de propor ações distintas, ajuizar demanda única em face do empregador e o INSS, cujo feito por força da EC n 45/2004 será processado e julgado pela Justiça do Trabalho, já que, no caso específico, a relação previdenciária é oriunda do contrato de emprego havido.
\end{abstract}

Mesmo com o excelente achado doutrinário sobre o assunto, a jurisprudência se posiciona no sentido de manter a competência na área da Administrativa Pública, por se tratar, segundo entendimento jurisprudencial e 
legal (art. 109, I, da Constituição Federal Brasileira), de ato praticado por agente Público. ${ }^{20}$

No entanto, independentemente deste retorno ser aceito ou não pelo empregador ou, se o segurado exercer serviço autônomo, há que se verificar quais as razões de tantos indeferimentos de pedidos de benefícios incapacitantes decorrentes de transtornos mentais oriundos do ambiente laboral.

Por esta razão, também foi destacado neste trabalho a discussão sobre a perspectiva prática das pericias judiciais e administrativas no âmbito tanto da Justiça do Trabalho como Previdenciária, sendo de fundamental importância, dada a relevância da prova pericial nas ações indenizatórias e/ou pedido de benefício previdenciário decorrente da doença ocupacional ou acidente de trabalho e sua utilidade como alicerce para uma avaliação justa e imparcial do Magistrado.

Diante destas considerações, há que ter uma reflexão acerca do direito à saúde como um direito humano fundamental, deve-se, assim elencar, em linhas gerais, a forma que se opera a avaliação pericial e algumas discussões polêmicas que gravitam em torno desta prática, abordando questões usuais presentes em todo o processo de produção de prova pericial, como critério para nomeação dos peritos e a importância da visita ao ambiente laboral durante a realização da perícia e a qualificação profissional deste expert para a realização da perícia. ${ }^{21}$

A presunção do INSS, portanto, quando analisada na justa medida, pode ser considerada extremamente prejudicial ao trabalhador e ao seu empregador.

20 PROCESSO CIVIL. CONFLITO DE COMPETÊNCIA. AÇÃO DE INDENIZAÇÃO POR DANOS MATERIAIS E MORAIS AJUIZADA CONTRA O INSSS. RESPONSABILIDADE DA ADMINISTRAÇÃO PÚBLICA. ATO PRATICADO POR AGENTE PÚBLICO. COMPETÊNCIA DA JUSTIÇA FEDERAL. 1. Cuida-se de conflito negativo de competência instaurado entre 0 Juízo Federal e o Juízo Estadual, nos autos de ação de indenização por danos materiais e morais ajuizada por empregado celetista contra o INSS, por ato praticado por médico-perito da autarquia. 2. A causa não se refere à ação de indenização por danos decorrentes de acidente de trabalho formulada pelo empregado contra o empregador, de modo que não incide o art. 114, VI, da Constituição da República. 3. Funda-se a acão na responsabilidade da Administracão Pública pelos atos praticados por seus agentes no exercício da funcão, conforme preceitua o $\$ 6^{\circ}$ do art. 37 da Carta Magna. Logo, a competência deve ser atribuída na conformidade do que dispõe a primeira parte do art. 109, I, da Carta Magna. 4. Conflito conhecido para declarar a competência da Justiça Federal, o suscitado (BRASIL,, STJ - CC: 106797 SP 2009/0140945-2, Relator: Ministro CASTRO MEIRA, Data de Julgamento: 14/10/2009, S1 - PRIMEIRA SEÇÃO, Data de Publicação: DJe 22/10/2009).(g.n.)

${ }^{21}$ Revista RST no 306, dezembro/2014. p. 112. 
Dada tal relevância, é de se verificar a quem cabe a responsabilidade ao pagamento de salário/benefício quando o trabalhador, ainda incapacitado, é liberado pelo perito do INSS e não é aceito tal "aptidão" pela empresa e pelo médico particular, devendo, por conta deste resultado, o responsável ser responsabilizado civilmente nos termos da Lei vigente à cada categoria.

\section{RESPONSABILIDADE QUANTO AO PAGAMENTO DO SALÁRIO DO SEGURADO APÓS SUSPENSÃO DO BENEFÍCIO PREVIDENCIÁRIO QUANDO O TRABALHADOR ESTIVER INCAPACITADO SEGUNDO DIAGNÓSTICO DO MÉDICO PARTICULAR E DA EMPRESA.}

A responsabilidade é uma categoria jurídica extensiva a todos os ramos do direito, público e privado e consiste no dever imposto a quem infligiu dano a outrem, em decorrência de violação de direito deste, de reparar o prejuízo.

No dizer de Nelson Nery Junior e Rosa Maria de Andrade Nery, a responsabilidade civil se assenta na conduta do agente (responsabilidade subjetiva) ou no fato da coisa ou no risco da atividade (responsabilidade objetiva). Sendo que, na responsabilidade objetiva o sistema fixa o dever de indenizar independentemente da culpa ou dolo do agente, já, na responsabilidade subjetiva há o dever de indenizar quando se demonstra o dolo ou a culpa do agente, na causação do fato que ocasionou o dano. Considera-se assim, o sistema de responsabilidade subjetiva como regra geral e o sistema de responsabilidade objetiva como exceção.(NERY JR, ANDRADE NERY, 2009, 2013, p. 785 e 934).

Tratando-se de responsabilidade civil pela prestação de serviços públicos, a responsabilidade do Estado é considerada objetiva, ou seja, aplicase o mesmo regime utilizado para administração pública (risco administrativo), norma esta, regida pelo art. $37, \S 6^{\circ}$, da Constituição Federal, por força do princípio da hierarquia.(CAVALIERI FILHO, 2014, p. 223 e 304).

Assim, verifica-se que o INSS, por ser entidade da Administração Pública Indireta, responde por atos de seus agentes, quando no exercício de funções públicas, defendendo os interesses da Administração, com fulcro no art. 37, § 6º , da Constituição Federal c/c art. 43, do Código Civil . 
A responsabilidade da pessoa jurídica de direito público no direito positivo brasileiro é consagrada pela teoria do risco administrativo, segundo os dispositivos acima e conforme entendimento jurisprudencial consolidado, sendo que, para que o Estado possa ser responsabilizado pelo prejuízo, basta a ocorrência do fato administrativo caracterizado pelo comportamento comissivo ou omissivo a ele imputado, o prejuízo e o nexo de causalidade entre o fato e o dano. ${ }^{22}$

Ainda, pose-se citar os ensinamentos de Caio Mário da Silva Pereira, citado por Rui Stoco (STOCO, 2004, p. 270), sobre a responsabilidade civil do Estado, em que leciona:

\begin{abstract}
Destaca-se a teoria do acidente administrativo, ou da falta impessoal do serviço, em que se não exige a verificação da culpa individual do agente, pois esta nem sempre se pode exatamente se positivar; basta comprovar a existência de uma falha objetiva do serviço público, ou o seu mau funcionamento, ou uma irregularidade qualquer que importe em desvio da normalidade, para que fique estabelecida a obrigação de reparar o dano".
\end{abstract}

Esclarece-se, primeiramente que, para o INSS, a emissão de CAT (Comunicado de Acidente de Trabalho) não basta para a comprovação de acidente de trabalho, porquanto a caracterização oficial do infortúnio é feita pelo setor de Perícia Médica deste Instituto nos afastamentos superiores a 30 dias, através de análise técnica para conferência do nexo entre o trabalho e o agravo.

Para elucidar os fatos que eventualmente estejam gerando dúvidas quanto ao nexo causal, a perícia médica da Previdência Social poderá ouvir testemunhas, efetuar pesquisas ou até mesmo realizar vistoria do local de trabalho, bem como solicitar documento Perfil Profissiográfico Previdenciário PPP diretamente ao empregador. (OLIVEIRA, 2009, p. 62).

Se o INSS entender que a o segurado/trabalhador está apto para o trabalho após os exames periciais e suspender o benefício previdenciário,

\footnotetext{
22 JUIZADOS ESPECIAIS DA FAZENDA PÚBLICA. CEB. FORNECIMENTO DE ENERGIA. SUSPENSÃO POR FALTA DE PAGAMENTO. FALHA NA PRESTAÇÃO DO SERVIÇO. TEORIA DO RISCO ADMINISTRATIVO. RESPONSABILIDADE OBJETIVA DO ESTADO (ARTIGO 37, § 6을 DA CF/1988). DANOS MORAIS CONFIGURADOS. (BRASIL, TJ-DF - ACJ: 20140110809809 DF 0080980-71.2014.8.07.0001, Relator: ANTÔNIO FERNANDES DA LUZ, Data de Julgamento: 28/10/2014, 2 2 a Turma Recursal dos Juizados Especiais Cíveis e Criminais do DF, Data de Publicação: Publicado no DJE : 30/10/2014 . p. 261.
} 
deverá ser responsabilizado se comprovado o contrário, porém, percebendo seu eventual equívoco, pode a qualquer tempo, reformar sua própria decisão, especialmente diante da relevância e natureza dos benefícios acidentários e/ou previdenciários.

Ainda, se a decisão, do processo administrativo for desfavorável ao segurado, resta ao trabalhador a possibilidade de ver atendida sua pretensão pela via judicial, entretanto, tem-se verificado que o empregado, vendo-se impossibilitado de trabalhar em vista da sua incapacidade ser constatada pela empresa e médico particular, ficará aguardando o desfecho da demorada ação judicial previdenciária sem salário e sem benefício, devendo-se, assim, responsabilizar o perito em caso de confirmado erro / equivoco no laudo pericial.

Entende-se, assim, que quando o INSS nega um benefício, toda a sociedade é afetada, não só o indivíduo, uma desordem criada de uma decisão, de uma demora que agrava a situação social do segurado, que causa perturbação na paz social, objetivo do Estado, podendo até exigir danos morais do Estado pelo prejuízo causado ao cidadão.

Da mesma forma, contempla-se que cabe ao Poder Público a obrigação de não somente prevenir o dano, adotando as medidas necessárias para excluir o risco do usuário, tanto quanto, se responsabiliza igualmente pelas falhas do serviço público em virtude da ação lesiva dos seus servidores e funcionários, segundo a conclusão da orientação jurisprudencial. Frise-se neste sentido o entendimento do Tribunal Regional Federal:

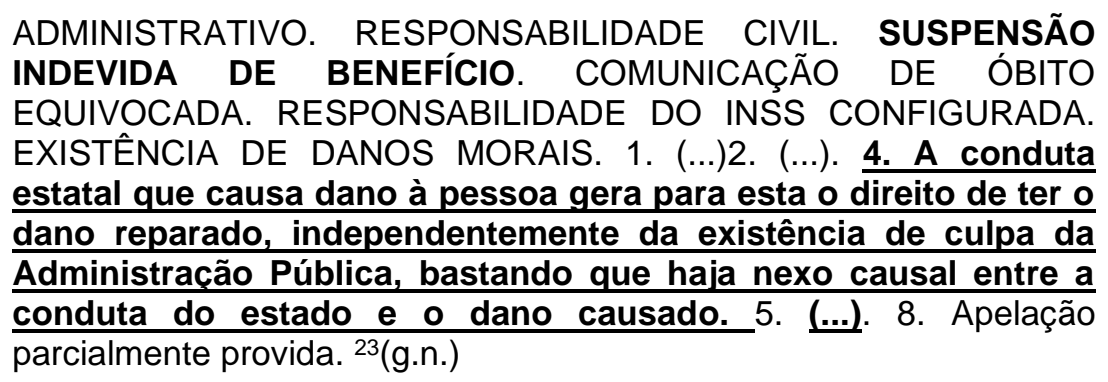

Conforme acima exposto, cabe ação de indenização por danos materiais e morais ajuizada por responsabilidade da Administração Pública contra 0

23 BRASIL TRF-5 - AC: 26764220124058400 , Relator: Desembargador Federal Cesar Carvalho, Data de Julgamento: 10/06/2014, Segunda Turma, Data de Publicação: 13/06/2014. 
INSS, por ato praticado por médico-perito da autarquia (agente público) no exercício da função, conforme preceitua o $\S 6^{\circ}$ do art. 37 da Carta Magna c/c com art 43, CC e o entendimento de Tribunais Regionais Federal, bem como do Superior Tribunal de Justiça.

Caberá, entretanto, ação regressiva (art. 934, CC) da empresa em face do INSS aos valores pagos indevidamente por aquela, se comprovado o erro do perito ao liberar o segurado, obrigando a empresa ao pagamento "indevido" do salário ao trabalhador até que se comprove sua efetiva incapacidade laboral, caso este decorrente da responsabilidade civil por ato próprio do agente público, entretanto, apenas há tese doutrinária neste sentido, a exemplo de Treviso.

Por outro lado, caberá ação regressiva do INSS contra a empresa, se comprovado que esta causou dano ao erário no caso de acidente de trabalho por insegurança no ambiente de trabalho (negligência), causador do infortúnio laboral, independentemente do pagamento do Seguro de Acidente de Trabalho (SAT) feito pela companhia, segundo entendimento do STJ. ${ }^{24}$

Assim, no que pertine à obrigação da empresa, resta indubitável dizer que quando há uma relação de trabalho onde se desenvolva o vínculo trabalhista e consequentemente deste vínculo institui-se o contrato de trabalho, os deveres e obrigações se estendem para ambos.

Infere-se, entretanto, que a existência de contrato de trabalho entre 0 patrão e o empregado é irrelevante para efeito de imposição de responsabilidade no caso de acidente, pois, nem mesmo a existência de um vínculo empregatício formal se exige, bastando para tanto, a comprovação de relação de trabalho ou a prestação de serviço a qualquer titulo, a alguém para que nasça a obrigação de reparar, segundo o dispositivo legal (art. $7^{\circ}$, XXVIII, da $\mathrm{CF} / 88$ e art. 186 , do CC).

24 PREVIDENCIÁRIO E PROCESSUAL CIVIL(...). CABIMENTO. AÇÃO REGRESSIVA MOVIDA PELO INSS CONTRA EMPRESA RESPONSÁVEL POR ACIDENTE DE TRABALHO. (..). PENSÃO POR MORTE. VÍNCULO PREVIDENCIÁRIO. AGRAVO NÃO PROVIDO.(...). (BRASIL, STJ - AgRg no REsp: 1293096 RN 2011/0273326-3, Relator: Ministro ARNALDO ESTEVES LIMA, Data de Julgamento: 15/10/2013, T1 - PRIMEIRA TURMA, Data de Publicação: DJe 23/10/2013). 
É no campo da teoria objetiva que se coloca a teoria do risco, pela qual cada um deve suportar os riscos da atividade a que se dedica, devendo indenizar quando causar dano por conduta decorrente de ato ilícito. (Art.927, parágrafo único, CCB, 2002).

Segundo Rui Stoco (2004, p. 745) a regra em relação à responsabilidade Civil, apenas quando haja previsão expressa em lei ou o dano decorra do exercício de atividade que, por sua natureza, implique em risco para os direitos de outrem, seja empregado ou terceiro, é que se poderá invocar o parágrafo único do artigo 927, do Código Civil.

Ato contínuo, estabelece como regra que o empregador é responsável perante seus empregados quando sua ação ou omissão causadora de danos decorrer de negligencia ou imprudência. E, como exceção, sua responsabilidade poderá ser objetiva quando explorar atividade comprovadamente de risco, de modo a colocar em perigo permanente a integridade de seis comandados. (STOCO, 2004 P. 745).

Com isso foi possível a integração do acidente de trabalho no sistema de previdência social (Art. 121 da Lei 8.213/91 "O pagamento, pela Previdência Social, das prestações por acidente do trabalho não exclui a responsabilidade civil da empresa ou de outrem").

Dada a importância da responsabilidade da empresa quanto à manutenção de um ambiente de trabalho seguro e equilibrado, bem como, em pagar o salário ao trabalhador em troca da prestação de seus serviços, esclarece-se que, quando este empregado estiver acometido por acidente do trabalho ou doença ocupacional também deve ser acobertado, tanto pela Previdência Social, como pela empresa.

O embate maior é quando o INSS suspende o benefício previdenciário do empregado quando o perito diagnostica aptidão para o labor e a empresa ao fazer o exame médico de retorno constata sua incapacidade.

A jurisprudência tem se manifestado no sentido de que cabe a empresa acatar o resultado do perito do INSS, porque, por ser ato administrativo, presume-se ser verdadeiro, devendo-se aceitar o empregado como apto, e, em contrapartida, em caso de não confirmar a capacidade do trabalhador, 
readequá-lo em outra função e adentrar com recurso contra a decisão do expert.

Caso contrário, se o empregador não suspender o funcionário e deixar de pagar seu salário, deverá arcar com posterior indenização substitutiva de salário e demais vantagens, haja vista que o empregado não pode ficar sem verba alimentar por ser parte hipossuficiente, sem condições de prover seu sustento e de sua família, configurando violação à dignidade da pessoa humana. Neste sentido:

ALTA MÉDICA CONCEDIDA PELO INSS. INCAPACIDADE CONSTADA PELO SETOR MÉDICO DA EMPRESA. CONFIGURAÇÃO DO DENOMINADO "LIMBO JURÍDICO TRABALHISTA-PREVIDENCIÁRIO". RECONHECIMENTO DO DIREITO À PERCEPÇÃO DE SALÁRIOS NO PERÍODO. (...) Ademais, na hipótese de concessão de licença remunerada, também é cabível ação patronal de reparação civil na Justiça Comum para reaver do INSS os salários pagos ao empregado durante o período em que foi considerado apto pelo órgão previdenciário e efetivamente estava incapacitado. O que não se admite é que o empregado considerado apto por atestado médico oficial fique sem receber salários e benefício previdenciário, pois assim haveria violação dos princípios da dignidade da pessoa humana e do valor social do trabalho. ${ }^{25}$ (g.n.)

Ademais, é de se enfatizar que comete manifesto abuso de direito a empresa que, se valendo da NR 7, considera o empregado inapto ao trabalho e o joga - sem se preocupar - na situação dramática de "limbo jurídico previdenciário", porém, não desconhecendo o "lado" da empresa que, identificando que o empregado não reúne condições de retornar ao trabalho, teme em permitir o trabalho com riscos de ocorrência/agravamento de acidente do trabalho. O zelo da empresa, nessas situações, é procedente, pois ela está obrigada a agir de forma a proteger a saúde e a segurança do trabalhador, na forma do art. 157 da CLT.

Outrossim, se o empregador entender que o trabalhador continua incapaz para retornar à sua função habitual, deverá, então, readaptá-lo em outra atividade compatível com a alegada limitação, mas sem considerar o contrato de trabalho como supostamente suspenso, também, poderá resolver administrativamente ou judicialmente junto ao INSS, comprovando esta 
inaptidão por exames complementares, podendo, ao final, ser ressarcido pelo suposto "prejuízo" causado pela "equivocada" liberação do segurado, conforme a jurisprudência acima exposta.

\section{CONCLUSÃO.}

Sabe-se que já houve avanço quanto às pesquisas científicas sobre a síndrome de burnout por parte da Psicologia e da Psiquiatria modernas, tendo certo domínio das origens, causas, tipologia, prevenção e tratamento de transtornos mentais, porém, verifica-se que falta um determinado avanço das gerações atuais no que concerne aos direitos humanos fundamentais de proteção da saúde mental no trabalho.

Verificou-se neste estudo que apesar da pouca aceitação da doença mental como acidente de trabalho por parte da perícia médica, muitas vezes por desconhecimento do perito, há Norma que estabelece a Síndrome de Bournout como doença ocupacional, bastando para tanto, comprovar que a moléstia surgiu em decorrência do trabalho ou da forma como o exercia no ambiente da empresa.

Constatou-se, da mesma forma, que a jurisprudência tem proferido entendimentos bem positivos neste sentido, responsabilizando o INSS, ou, conforme o caso, o empregador, ao pagamento do benefício previdenciário em caso de suspensão indevida para aquele, ou, retorno ao trabalho, com readaptação funcional, bem como indenização substitutiva do tempo em que o trabalhador ficou afastado em decorrência da doença ocupacional, sem salário e sem benefício, por parte do empregador que não aceitou o empregado após aptidão constatada pela perícia previdenciária.

Restou claro que 0 artigo $37, \S 6^{\circ}$, da CF/88, consagra a responsabilidade objetiva das pessoas jurídicas de direito público, dispondo que responderão pelos danos que seus agentes, nessa qualidade, causarem a terceiros, bem como, que os empregadores que exercem atividade de risco serão responsabilizados pela reparação de danos sofridos por seus funcionários em caso de acidente de trabalho. Atente-se: dispensada a prova de dolo ou culpa resta, porém, ao prejudicado o ônus de demonstrar que houve 
o dano e que este foi causado por agente da administração Pública ou, no caso de empresa, no ambiente de trabalho ou a serviço desta.

Em breves pinceladas, foi apresentado no decorrer da pesquisa, a opinião de Treviso, apresentando-se como uma solução plausível de ser discutida em outro momento, a importância de se manter a competência na Justiça do Trabalho, como forma de resolver a situação do limbo jurídico previdenciário/trabalhista, o qual, poderia ser solucionado com a manutenção de somente uma seara, ou seja, a trabalhista, tendo em vista ter a participação de todas as partes em um mesmo processo, em particular a perícia, a qual pode ser contestada nesta mesma área por aqueles, como medida de economia e celeridade processual.

Infere-se, neste diapasão que as causas jurídicas dessa eficácia de direitos e deveres são diversas, destacando-se, por conseguinte que: paga o INSS porque 0 acidente ocorre e há os recolhimentos compulsórios para a previdência social (o empregado também colabora); paga o empregador sozinho pelo direito comum pela ilicitude da culpa (dimensão subjetiva), e por último, poderá haver a ação regressiva, tanto ajuizada pelo INSS contra a empresa, quanto pelo empregador em face da Previdência, em caso de comprovado ato ilícito de uma das partes.

A dificuldade de solução deste "limbo jurídico" é manifestada pela carência de uma disciplina legal clara e específica para esse quadro fático. $\mathrm{Na}$ lacuna da lei, entende-se poderia ser resolvida por meio de negociação coletiva. Daí, quando verificada essa hipótese, basta recorrer ao que ficou ajustado na convenção coletiva ou acordo coletivo. Em não havendo esse recomendado ajuste coletivo, crê-se, então, que a parte mais vulnerável não pode ser prejudicada.

Outra solução encontrada, seria de 0 empregador readaptar 0 funcionário em uma atividade compatível com a alegada limitação, em caso de o médico atestar pela incapacidade na função habitual, mas sem considerar o contrato suspenso, ao menos até que possa solucionar administrativamente ou judicialmente junto ao INSS a situação do segurado, podendo até, supostamente, propor ação de regresso contra o INSS em caso de configurar 
por exames complementares a incapacidade laboral do obreiro, demonstrando inegavelmente o "erro pericial".

Por outro lado, verificou-se que o INSS já vem adentrando com este tipo de ação contra as empresas que tem causado acidentes de trabalho por ausência de um ambiente laboral seguro, como forma de suprir o prejuízo causado pelas mesmas e, até mesmo, "educar" estes empresários, ações estas que a jurisprudência tem se manifestado positivamente, condenando os empregadores ao ressarcimento das despesas decorrente destes infortúnios, quando comprovada a negligencia e/ou imprudência.

Quando o assunto é saúde mental, as consequências pela falta de informação, aliada a diversos fatores culturais, como a estigmatização sobre transtornos mentais decorrente do trabalho, melhor conhecida como Síndrome de Burnout, ganham contornos alarmantes, surgindo, assim, a necessidade de um trabalho multidisciplinar, com a conscientização e atualização de médicos, peritos, trabalhadores, empregadores e todos os agentes que estão envolvidos com a segurança e medicina do trabalho a respeito da importância de se aprimorar no assunto, a ponto de tentar amenizar ou mesmo solucionar o problema.

É somente desta maneira que buscar-se-á soluções plausíveis a respeito deste dilema tão frequente na atualidade e por diversas razões oriundas do mundo globalizado e assoberbado tecnologicamente, onde as empresas apenas pregam metas sem, no entanto, encontrar formas acessíveis de resolvê-las em tempo real, ou seja, em horário de trabalho.

\section{REFERÊNCIAS}

BRASIL. Códigos Civil; Processo Civil e Constituição Federal/Obra coletiva de autoria da Editora Saraiva com a colaboração de Antonio Luiz de Toledo Pinto, Márcia Cristina Vaz dos Santos Windt e Livia Céspedes, 6. ed. São Paulo: Saraiva, 2010.

CAVALHIERI FILHO, Sergio. Programa de Responsabilidade Civil. 11. ed. São Paulo. Atlas, 2014.

GOUVEIA, Carlos Alberto Vieira de, Beneficio por incapacidade \& Pericia Médica. Manual Prático. Curitiba, Juruá. 2012. 
KRAVCHYCHYN, Jefferson Luis, (et AL). Pratica Processual Previdenciária: Administrativa e Judicial. 4. ed. Ver. e atual - Rio de Janeiro: Forense, 2013.

MENDES, Maria Aparecida de Borba. A Síndrome de Burnout nos Trabalhadores Bancários. Artigo apresentado na Pós Graduação da UNICURITIBA e enviado para publicação na Revista Percurso, Sociedade, Natureza e Cultura, Curitiba, ID 881, ISSN: 2316-7521, 2014.

NERY JÚNIOR, e Rosa Maria de Andrade Nery e Nelson, Código Civil Comentado, 7. ed. Ed. Revista dos Tribunais, 2009.

Código Civil Comentado, 10. ed. Ed. Revista dos Tribunais, 2013.

OLIVEIRA, Sebastião Geraldo de. Indenizações por Acidente do Trabalho ou Doença Ocupacional. 5. ed. São Paulo: LTr, 2009.

RODRIGUES, Avelino Luiz; CAMPOS, Elisa Maria Parahyba; VALENTE, Guilherme Borges. Qualidade de vida e Burnout em médicos. In: ROSSI, Ana Maria; PERREWÉ, Pamela L.; MEURS, James A. (Orgs.). Stress e qualidade de vida no trabalho: stress social - enfrentamento e prevenção. São Paulo: Atlas, 2011. p. 140.

SAVARIS, José Antonio, Curso de perícia Judicial Previdenciária, 2. ed. Alteridade Editora, Curitiba, 2014.

SERAU JUNIOR, Marco Aurélio (coord). Juizados Especiais Federais: Reflexões nos dez anos de sua instalação./Marco Aurélio Serau Jr., Denis Donoso (coords)./Curitiba: Juruá, 2012.

SILVEIRA, Carla Rita Branchhi. Revista RST no 306, Parte Geral, Artigo: Pericia Judicial na Justiça do Trabalho: Aspectos polêmicos. 2014

STOCO, Rui. Tratado de Responsabilidade Civil. 6. ed., RT, São Paulo. 2004.

TREVISO, Marco Aurélio Marsiglia. E-Book - A Competência da Justiça do Trabalho, a Incapacidade Laborativa do Trabalhador e o Restabelecimento de Benefícios Previdenciários - (7409.1): Na Perspectiva da Dignidade da pessoa Humana e do Mínimo existencial. São Paulo. LTr, 2012. 